\title{
Effect of Integrated Nutrient Management on Growth and Yield Attributes of Potato (Solanum tuberosum L.)
}

\author{
Gurwinder Singh*, Arun Kumar, Gurpreet Singh, Mandeep Kaur, \\ Mansukh Singh Jatana and Sunita Rani
}

Department of Agronomy, School of Agriculture, Lovely Professional University, JalandharDelhi G.T Road (NH-1), Phagwara, Punjab, India

Department of Vegetable, School of Agriculture, Lovely Professional University, JalandharDelhi G.T Road (NH-1), Phagwara, Punjab, India

Department of Agronomy, Lovely Professional University, Phagwara, 144441, Punjab, India

*Corresponding author

\section{A B S T R A C T}

Effect of integrated nutrient management on growth, quality and yield of potato (kufri pukhraj) were studied in alluvial soil at experimental farm of lovely professional university

\section{Keywords}

Potato, Azotobacter,

Vermicompost,

Organic manures,

Organic carbon

Article Info

Accepted:

18 May 2018

Available Online:

10 June 2018
2017-2018. The experiment was laid out in Randomized complete block design with eleven treatments were set and each replicate three times. Totally eleven treatments in which one control, two treatments consist $100 \%$ RDF and 75\% RDF alone and remaining eight treatments consist combination of inorganic fertilizers and organic manures. Growth attributes and yield attributes were recorded at the time of harvest. Integrated use of synthetic fertilizers, organic manures and biofertilizers showed the significant impact on growth and yield attributes of potato. Result indicate that the application of 75\% RDF + 2 tonnes ha ${ }^{-1} \mathrm{FYM}+1$ tones $\mathrm{ha}^{-1}$ Vermicompost $+20 \mathrm{~kg} \mathrm{ha}^{-1}$ Sulphur $+20 \mathrm{~kg} \mathrm{ha}^{-1}$ Zinc sulphate + Azotobacter (seed treatment) showed significant positive impact on fresh weight $\left(\right.$ plant $\left.^{-1}\right)$, tuber weight $\left(\right.$ plant $\left.^{-1}\right)$, tuber numbers $\left(\right.$ plant $\left.^{-1}\right)$ and tuber yield (tonnes ha ${ }^{-1}$ ) as compared to $100 \%$ RDF and control. The application of $100 \%$ RDF +2 tonnes ha ${ }^{-1}$ FYM +1 tones ha ${ }^{-1}$ Vermicompost $+20 \mathrm{~kg} \mathrm{ha}^{-1}$ Sulphur $+20 \mathrm{~kg} \mathrm{ha}^{-1}$ Zinc sulphate showed positive impact on dry weight. Application of $75 \% \mathrm{RDF}+2$ tonnes $^{-1} \mathrm{a}^{-1} \mathrm{FYM}+1$ tones $^{-1}$ Vermicompost $+20 \mathrm{~kg} \mathrm{ha}^{-1}$ Sulphur $+20 \mathrm{~kg} \mathrm{ha}^{-1}$ Zinc sulphate + Azotobacter (seed treatment) was more remunerative for sustainable production of potato.

\section{Introduction}

Potato (Solanum tuberosum L.) is a most important tuber crop of the world, belong to family Solanaceae. It is also known as king of tuber crops and poor man's food. The origin place of potato is South America (Peru). It is the fourth most important food crop in the world after rice, wheat and maize. Next to the cereals, it is the only crop, which could supplement the needs of food of our country. About $90 \%$ of potato in India is grown under short day conditions during winter months. Out of this, about $85 \%$ accounts under the Indo-Gangetic plains comprising the states of UP, Bihar, West Bengal, Punjab and Haryana. 
It occupies an area of 1.93 million tones ha- ${ }^{1}$ in country with a production of 42.43 million tonnes ha ${ }^{-1}$ (Anonymous 2013). Potato being a shallow rooted crop is more responsive to the application of nitrogen, phosphorus and potassium as compared to other solanaceous crops like tomato and pepper (Perrenoud, 1999).

Inorganic fertilizer is the main source of nutrients use for potato cropping. However, continuous application of Inorganic fertilizer causes nutritional imbalance and adverse effects on physic-chemicals and biological properties of soil. On the other hand, the price of inorganic fertilizers has increased to an extent that those are out of reach of the small and marginal farmers. So it has become difficult for farmers to apply such expensive inputs for a crop of marginal returns.

The use of biofertilizers and organic in such situation is, therefore, a practically paying proposal. Integrated application of half of the recommended dose of fertilizer + biofertilizer could produce more or less the same economic yields, besides a saving of half of the recommended dose of $\mathrm{N}$ and $\mathrm{P}$ (Kumar and Shivay 2010). Thus, the integrated nutrient management could be a key factor for producing and maintain high level of tuber yield in sustain manner.

\section{Materials and Methods}

\section{Location of experimental site}

The experiment was conducted at the experimental Farm of the Department of Agriculture, Lovely Professional University, Jalandhar, Punjab (India) during 2017-18. The latitude $31^{\circ} 22^{\prime} 31.81^{\prime} \mathrm{N}$ and $75^{\circ} 23^{\prime} 03.02 \mathrm{E}$ longitude with altitude of $252 \mathrm{~m}$ above sea level, which falls under the central plain zone of Agra climate zone of Punjab. The soil was sandy loam with $\mathrm{pH}$ 7.5. The available $\mathrm{N}, \mathrm{P}$ and $\mathrm{K}$ content of soil were 230, 14.2 and 278.4 $\mathrm{kg}$ ha- ${ }^{1}$, respectively with organic carbon 0.58 $(\%)$ and Electrical conductivity $0.26\left(\mathrm{dSm}^{-}{ }^{1}\right)$.

\section{Experimental detail}

The experiment was laid out in Randomized complete block design with eleven treatments were set and each replicate three times. Totally eleven treatments in which one control, two treatments consist $100 \%$ RDF and $75 \%$ RDF alone and remaining eight treatments consist combination of inorganic fertilizers, organic manures. Table 1 show the detail of treatments.

\section{Agronomic practices}

Potato variety Kufri Pukhraj was used in this research work. In addition to this, half dose of nitrogen and full dose of phosphorus and potassium were also applied as per treatment through urea, SSP and muriate of potash, respectively. The remaining half dose of nitrogen was applied at the time of earthing up. Potato tubers were planted in the ridge 60 $\mathrm{cm}$ apart with plant to plant distance of $20 \mathrm{~cm}$ in the October, 2017. The 100\% RDF contained $180 \mathrm{~kg} \mathrm{~N}, 65 \mathrm{~kg}$ phosphorous, $65 \mathrm{~kg}$ Potassium per hectare and $75 \%$ RDF contained $135 \mathrm{~kg} \mathrm{~N}, 16.3 \mathrm{~kg}$ phosphorous and $16.3 \mathrm{~kg}$ potassium per hectare.

\section{Data collection}

The growth attributes (fresh weight and dry weight) and yield attributes (tuber number, tuber weight and tuber yield) were taken at harvesting i.e. 80 days after planting.

\section{Statistical analysis}

Data were analyzed by Duncan's Multiple Range Tests (DMRT) for separation of means with a probability $\mathrm{p}<0.05$. Difference between mean values were evaluated by Analysis of 
Variance (ANOVA) using the software SPSS 16.

\section{Results and Discussion}

\section{Growth attributes}

\section{Fresh weight (gram plant $\left.{ }^{-1}\right)$}

The maximum fresh weight (126.07 $\mathrm{g} \mathrm{plant}^{-1}$ ) was recorded with application of $75 \% \mathrm{RDF}+$ 2 tonnes ha ${ }^{-1}+20 \mathrm{~kg} \mathrm{ha}^{-1}$ Sulphur $+20 \mathrm{~kg} \mathrm{ha}^{-1}$ Zinc sulphate +1 tonnes ha ${ }^{-1}$ Vermicompost + Azotobacter (seed treatment) superior to $100 \%$ RDF and control (Table 2). This might be due to integration of inorganic fertilizer, organic manure and biofertilizers because vermicompost influence the nitrification inhibition properties of soil and biofertilizer fix atmospheric nitrogen in soils which enhance the vegetative growth of plant. Similar result was recorded by Baishya et al., (2013) and Solanke et al., (2009).

\section{Dry weight (gram palnt ${ }^{-1}$ )}

The dry weight of plant was found maximum (25.76g plant ${ }^{-1}$ ) with the application of $100 \%$ $\mathrm{RDF}+2$ tonnes ha ${ }^{-1}+20 \mathrm{~kg} \mathrm{ha}^{-1}$ sulphur +20 $\mathrm{kg} \mathrm{ha}{ }^{-1}$ zinc sulphate +1 tonnes $\mathrm{ha}^{-1}$ vermicompost superior to $100 \% \mathrm{RDF}$ and control (Table 2). This might be due to integrated use of organic manures and biofertilizer along with inorganic fertilizers. Organic manure and biofertilizer increase the efficiency of nitrogen and phosphorous which assimilate more photosynthates and better trancolation resulting in higher vegetative growth. Similar result was observed by Baishya et al., (2013) and Banjare et al., (2012).

\section{Yield attributes}

\section{Tuber numbers $\left(\right.$ plant $\left.^{-1}\right)$}

The highest (16.86) number of tubers is recorded with the application of $75 \% \mathrm{RDF}+2$ tonnes $\mathrm{ha}^{-1}+20 \mathrm{~kg} \mathrm{ha}^{-1}$ sulphur $+20 \mathrm{~kg} \mathrm{ha}^{-1}$ zinc sulphate +1 tonnes ha ${ }^{-1}$ vermicompost + Azotobacter (seed treatment) which was superior to $100 \%$ RDF and control (Table 3). This might be due to use of organic sources along with inorganic fertilizers because organic sources of nutrients improved the soil aeration, root development and increased microbial and biological activities in the rhizosphere. Similar result found was found by Solanke et al., (2009) and Jaipaul et al., (2011).

Table.1 Treatment detail

\begin{tabular}{|c|c|}
\hline T0 & Control \\
\hline $\mathbf{T 1}$ & $100 \% \mathrm{RDF}$ \\
\hline $\mathbf{T 2}$ & $100 \%$ RDF +2 tonnes ha ${ }^{-1} \mathrm{FYM}+20 \mathrm{~kg} \mathrm{ha}^{-1}$ Sulphur \\
\hline T3 & $100 \%$ RDF +2 tonnes ha ${ }^{-1} \mathrm{FYM}+20 \mathrm{~kg} \mathrm{ha}^{-1}$ Sulphur $+20 \mathrm{~kg} \mathrm{ha}^{-1}$ Zinc sulphate \\
\hline T4 & $\begin{array}{l}100 \% \text { RDF }+2 \text { tonnes ha }{ }^{-1} \text { FYM }+20 \mathrm{~kg} \mathrm{ha}^{-1} \text { Sulphur }+20 \mathrm{~kg} \mathrm{ha}^{-1} \text { Zinc sulphate }+1 \text { tonnes ha-1 } \\
\text { Vermicompoist }\end{array}$ \\
\hline T5 & $\begin{array}{l}100 \% \text { RDF }+2 \text { tonnes ha }{ }^{-1} \mathrm{FYM}+20 \mathrm{~kg} \mathrm{ha}^{-1} \text { Sulphur }+20 \mathrm{~kg} \mathrm{ha}^{-1}{\text { Zinc sulphate }+1 \text { tonnes ha }^{-1} \text { Vermicompoist }}_{+} \text {Azotobacter (seed treatment) }\end{array}$ \\
\hline T6 & $75 \% \mathrm{RDF}$ \\
\hline T7 & $75 \%$ RDF + 2 tonnes ha ${ }^{-1}$ FYM + $20 \mathrm{~kg} \mathrm{ha}^{-1}$ Sulphur \\
\hline $\mathbf{T 8}$ & $75 \%$ RDF +2 tonnes ha ${ }^{-1} \mathrm{FYM}+20 \mathrm{~kg} \mathrm{ha}^{-1}$ Sulphur $+20 \mathrm{~kg} \mathrm{ha}^{-1}$ Zinc sulphate \\
\hline T9 & $75 \% \mathrm{RDF}+2$ tonnes ha ${ }^{-1} \mathrm{FYM}+20 \mathrm{~kg} \mathrm{ha}^{-1}$ Sulphur $+20 \mathrm{~kg} \mathrm{ha}^{-1}$ Zinc sulphate +1 tonnes ha $^{-1}$ Vermicompoist \\
\hline T10 & $\begin{array}{l}75 \% \mathrm{RDF}+2 \text { tonnes ha }{ }^{-1} \mathrm{FYM}+20 \mathrm{~kg} \mathrm{ha}^{-1} \text { Sulphur }+20 \mathrm{~kg} \mathrm{ha}^{-1} \text { Zinc sulphate }+1 \text { tonnes ha }{ }^{-1} \text { Vermicompoist } \\
+ \text { Azotobacter (seed treatment) }\end{array}$ \\
\hline
\end{tabular}


Table.2 Effect of integrated nutrient management on growth attributes of potato

\begin{tabular}{|l|c|c|}
\hline Treatments & Fresh weight $\left(\right.$ g plant $\left.^{\mathbf{1}}\right)$ & Dry weight $($ g plant \\
\hline T0 & ) \\
\hline T1 & $91.9^{\mathrm{f}} \pm 0.2$ & $15.93^{\mathrm{e}} \pm 0.88$ \\
\hline T2 & $115.53^{\mathrm{d}} \pm 1.48$ & $24.26^{\mathrm{abc}} \pm 0.46$ \\
\hline T3 & $113.8^{\mathrm{de}} \pm 0.34$ & $24.93^{\mathrm{ab}} \pm 0.33$ \\
\hline T4 & $115.13^{\mathrm{d}} \pm 0.58$ & $25.36^{\mathrm{a}} \pm 0.74$ \\
\hline T5 & $122^{\mathrm{c}} \pm 0.46$ & $25.76^{\mathrm{a}} \pm 0.44$ \\
\hline T6 & $124.13^{\mathrm{abc}} \pm 0.3$ & $24.30^{\mathrm{abc}} \pm 1.36$ \\
\hline T7 & $111.93^{\mathrm{e}} \pm 0.88$ & $21.26^{\mathrm{d}} \pm 0.52$ \\
\hline T8 & $122.67^{\mathrm{bc}} \pm 0.63$ & $22.36^{\mathrm{d}} \pm 0.23$ \\
\hline T9 & $122.6^{\mathrm{bc}} \pm 0.69$ & $22.86^{\mathrm{bcd}} \pm 0.76$ \\
\hline T10 & $124.6^{\mathrm{ab}} \pm 0.64$ & $24.30^{\mathrm{abc}} \pm 0.58$ \\
\hline
\end{tabular}

The mean followed by different letters are significantly different at $\mathrm{p}<0.05$, according to DMRT (Dun can's Multiple Range Test) for separation of means.

Note - T0 - control, T1 - (100\% RDF, T2 - 100\% RDF + 2tonnes FYM/ha + 1tonnes + 20kg Sulphur/ha), T2 $(100 \% \mathrm{RDF}+2 \mathrm{t} \mathrm{FYM} / \mathrm{ha}+20 \mathrm{~kg} \mathrm{~S} / \mathrm{ha}+20 \mathrm{~kg} \mathrm{ZnSO} 4 / \mathrm{ha}), \mathrm{T} 4-(100 \% \mathrm{RDF}+2 \mathrm{t} \mathrm{FYM} / \mathrm{ha}+20 \mathrm{~kg} \mathrm{~S} / \mathrm{ha}+20 \mathrm{~kg}$ $\mathrm{ZnSO} / \mathrm{ha}+1 \mathrm{t}$ vermicompost/ha), T5 - (100\% RDF + 2t FYM/ha + 20kg S/ha $+20 \mathrm{~kg} \mathrm{ZnSO} 4 / \mathrm{ha}+1 \mathrm{t}$ vermicompost/ha + Azotobacter (Seed treatment)), T6 - 75\% RDF, T7 - (75\% RDF + 2t FYM/ha + $20 \mathrm{~kg} \mathrm{~S} / \mathrm{ha}$ ), T8 $-(75 \% \mathrm{RDF}+2 \mathrm{t} \mathrm{FYM} / \mathrm{ha}+20 \mathrm{~kg} \mathrm{~S} / \mathrm{ha}+20 \mathrm{~kg} \mathrm{ZnSO} 4 / \mathrm{ha}), \mathrm{T} 9-(75 \% \mathrm{RDF}+2 \mathrm{t} \mathrm{FYM} / \mathrm{ha}+20 \mathrm{~kg} \mathrm{~S} / \mathrm{ha}+20 \mathrm{~kg}$ $\mathrm{ZnSO} 4 / \mathrm{ha}+1 \mathrm{t}$ vermicompost/ha), T10 $-75 \% \mathrm{RDF}+2 \mathrm{t} \mathrm{FYM} / \mathrm{ha}+20 \mathrm{~kg} \mathrm{~S} / \mathrm{ha}+20 \mathrm{~kg} \mathrm{ZnSO} 4 / \mathrm{ha}+1 \mathrm{t}$ vermicompost/ha + Azotobacter (Seed treatment).

Table.3 Effect of integrated nutrient management on yield attributes of potato

\begin{tabular}{|l|l|l|l|}
\hline Treatments & Tuber numbers (plant-1) & Tuber weight $(g$ plant-1) & Yield (tonnes ha-1) \\
\hline T0 & $5.73^{\mathrm{e}} \pm 0.17$ & $125.27^{\mathrm{h}} \pm 3.44$ & $9.02^{\mathrm{h}} \pm 0.24$ \\
\hline T1 & $13.20^{\mathrm{c}} \pm 0.5$ & $267.26^{\mathrm{e}} \pm 6.44$ & $19.24^{\mathrm{e}} \pm 0.46$ \\
\hline T2 & $13.20^{\mathrm{c}} \pm 0.52$ & $296.25^{\mathrm{d}} \pm 2.16$ & $21.33^{\mathrm{d}} \pm 0.15$ \\
\hline T3 & $13.93^{\mathrm{c}} \pm 0.24$ & $297.50^{\mathrm{cd}} \pm 1.25$ & $21.42^{\mathrm{cd}} \pm 0.09$ \\
\hline T4 & $15.40^{\mathrm{b}} \pm 0$ & $311.06^{\mathrm{bc}} \pm 2.8$ & $22.39^{\mathrm{bc}} \pm 0.2$ \\
\hline T5 & $16.06^{\mathrm{ab}} \pm 0.06$ & $325.27^{\mathrm{b}} \pm 4.33$ & $23.42^{\mathrm{b}} \pm 0.31$ \\
\hline T6 & $11.40^{\mathrm{d}} \pm 0.72$ & $207.38^{\mathrm{g}} \pm 7.72$ & $14.93^{\mathrm{g}} \pm 0.55$ \\
\hline T7 & $13.26^{\mathrm{c}} \pm 0.35$ & $249.30^{\mathrm{f}} \pm 5.36$ & $17.95^{\mathrm{f}} \pm 0.38$ \\
\hline T8 & $13.66^{\mathrm{c}} \pm 0.33$ & $254.91^{\mathrm{ef}} \pm 6.86$ & $18.35^{\mathrm{e}} \pm 0.49$ \\
\hline T9 & $15.66^{\mathrm{b}} \pm 0.06$ & $320.27^{\mathrm{b}} \pm 3.2$ & $23.06^{\mathrm{b}} \pm 0.23$ \\
\hline T10 & $16.86^{\mathrm{a}} \pm 0.06$ & $350.55^{\mathrm{a}} \pm 4.33$ & $25.24^{\mathrm{a}} \pm 0.31$ \\
\hline
\end{tabular}

The mean followed by different letters are significantly different at $\mathrm{p}<0.05$, according to DMRT (Dun can's Multiple Range Test) for separation of means.

Note - T0 - control, T1 - (100\% RDF, T2 - 100\% RDF + 2tonnes FYM/ha + 1tonnes + 20kg Sulphur/ha), T2 $(100 \% \mathrm{RDF}+2 \mathrm{t} \mathrm{FYM} / \mathrm{ha}+20 \mathrm{~kg} \mathrm{~S} / \mathrm{ha}+20 \mathrm{~kg} \mathrm{ZnSO} / \mathrm{ha}), \mathrm{T} 4-(100 \% \mathrm{RDF}+2 \mathrm{t} \mathrm{FYM} / \mathrm{ha}+20 \mathrm{~kg} \mathrm{~S} / \mathrm{ha}+20 \mathrm{~kg}$ $\mathrm{ZnSO} / \mathrm{ha}+1 \mathrm{t}$ vermicompost/ha), T5 - (100\% RDF $+2 \mathrm{t} \mathrm{FYM} / \mathrm{ha}+20 \mathrm{~kg} \mathrm{~S} / \mathrm{ha}+20 \mathrm{~kg} \mathrm{ZnSO} 4 / \mathrm{ha}+1 \mathrm{t}$ vermicompost/ha + Azotobacter (Seed treatment)), T6 - 75\% RDF, T7 - (75\% RDF + 2t FYM/ha $+20 \mathrm{~kg} \mathrm{~S} / \mathrm{ha}), \mathrm{T} 8$ $-(75 \% \mathrm{RDF}+2 \mathrm{t} \mathrm{FYM} / \mathrm{ha}+20 \mathrm{~kg} \mathrm{~S} / \mathrm{ha}+20 \mathrm{~kg} \mathrm{ZnSO} 4 / \mathrm{ha}), \mathrm{T} 9-(75 \% \mathrm{RDF}+2 \mathrm{t} \mathrm{FYM} / \mathrm{ha}+20 \mathrm{~kg} \mathrm{~S} / \mathrm{ha}+20 \mathrm{~kg}$ $\mathrm{ZnSO} / \mathrm{ha}+1 \mathrm{t}$ vermicompost/ha), T10 $-75 \% \mathrm{RDF}+2 \mathrm{t} \mathrm{FYM} / \mathrm{ha}+20 \mathrm{~kg} \mathrm{~S} / \mathrm{ha}+20 \mathrm{~kg} \mathrm{ZnSO} 4 / \mathrm{ha}+1 \mathrm{t}$ vermicompost/ha + Azotobacter (Seed treatment). 


\section{Tuber weight (gram plant ${ }^{-1}$ )}

The highest (350.55 $\mathrm{g} \mathrm{plant}^{-1}$ ) tuber weight was recorded with the application $75 \% \mathrm{RDF}+$ 2 tonnes ha ${ }^{-1}+20 \mathrm{~kg} \mathrm{ha}^{-1}$ sulphur $+20 \mathrm{~kg} \mathrm{ha}^{-1}$ zinc sulphate +1 tonnes ha $^{-1}$ vermicompost + Azotobacter (seed treatment) which was superior to $100 \%$ RDF and control (Table 3). This might be due to combined use of organic and inorganic fertilizers, which provide balance nutrition to plant. Similar result was found by Kate et al., (2005).

\section{Yield (tonnes ha-1)}

The highest (25.24 tonnes $\mathrm{ha}^{-1}$ ) tuber yield was recorded with the application $75 \% \mathrm{RDF}+$ 2 tonnes ha ${ }^{-1}+20 \mathrm{~kg} \mathrm{ha}^{-1}$ sulphur $+20 \mathrm{~kg} \mathrm{ha}^{-1}$ zinc sulphate +1 tonnes ha $^{-1}$ vermicompost + Azotobacter (seed treatment) which was superior to $100 \%$ RDF and control (Table 3). This might be due to application of fertilizers in combination with organic manure which increased the nutrient-use efficiency through modification of soil physical condition, and resulted in higher total uptake of nutrients because of better root penetration leading to better absorption of nutrients and moisture. Similar result was found by Narayan et al., (2013) and Khurana et al., (2005).

Based on the present study it was concluded that the integrated use of inorganic fertilizers and organic manures was significantly improve the vegetative growth of plant and increase the production of potato in sustain manner. Integrated nutrient management play a key role in sustainable agriculture.

\section{References}

Anonymous, 2013 a. National Horticulture Board. Ministry of Agriculture. Government of India, Gurgaon.
Anonymous, 2013 b. Directorate of Horticultural State Govt., Chhattisgarh, Raipur.

Baishya, L. K., Gupta, V. K., Lal, S. S., Das, B. K and Kumar, M., 2013. Effect of bio fertilizers on growth and yield of potato in northeastern hills of India. Journal of Potato. 32: 3-4.

Banjare, S., 2012. Study on the effect of different levels of nitrogen in the form of urea on potato production (Doctoral dissertation, Indira Gandhi Krishi Vishwavidyalaya Raipur) pp. 82-83.

Imas, P. and Bansal, S.K., 1999, December. Potassium and integrated nutrient management in potato. In Global conference on potato (Vol. 611).

Jaipaul, Sharma, S. and Sharma, A.K., 2011. Effect of organic fertilizers on growth, yield and quality of potato under rain fed conditions of central Himalayan Region of uttarakhand. Journal of Potato. 38 (2): 176-181.

Kate, D.M., Solanke, A.V., Tiwari, T.K. and Nemade, S.M., 2005. Growth and yield of potato cultivars as affected by integrated nutrient management system. Journal of Maharashtra Agricultural Universities. 30(2): 236237.

Khurana, S.C. and Bhutani, R.D., 2005. Effect of FYM, biofertilizer and inorganic fertilizer on potato. Potato Journal. 32: 3-4

Kumar, M., Baishaya, L.K., Ghosh, D.C., Gupta, V.K., Dubey, S.K., Das, A. and Patel, D.P., 2012. Productivity and soil health of potato (Solanum tuberosum L.) field as influenced by organic manures, inorganic fertilizers and biofertilizers under high altitudes of eastern Himalayas. Journal of Agricultural Science. 4(5): 223.

Narayan, S., Kanth, R.H., Narayan, R., Khan, F.A., Singh, P. and Rehman, S.U., 2013. Effect of integrated nutrient 
management practices on yield of potato. Journal of potao. 40(1): 84-86.

Solanke, A.V., Shete, B.T. and Dhage, V.J., 2009. Growth and yield of potato as influenced by integrated nutrient management. Annals of Plant Physiology. 23(2): 189-191.

\section{How to cite this article:}

Gurwinder Singh, Arun Kumar, Gurpreet Singh, Mandeep Kaur, Mansukh Singh Jatana and Sunita Rani. 2018. Effect of Integrated Nutrient Management on Growth and Yield Attributes of Potato (Solanum tuberosum L.). Int.J.Curr.Microbiol.App.Sci. 7(06): 2051-2056. doi: https://doi.org/10.20546/ijcmas.2018.706.242 